\title{
COMPARATIVE ANALYSIS OF THE QUALITY PARAMETERS AND THE FATTY ACID COM- POSITION OF TWO ECONOMICALLY IMPORTANT BALTIC FISH: COD, GADUS MORHUA AND FLOUNDER, PLATICHTHYS FLESUS (ACTINOPTERYGII) SUBJECTED TO ICED STORAGE
}

\author{
Grzegorz TOKARCZYK ${ }^{1 *}$, Grzegorz BIENKIEWICZ ${ }^{2}$, and Jacek SURYN ${ }^{3}$ \\ ${ }^{1}$ Division of Food Technology, West Pomeranian University of Technology, Szczecin, Poland \\ ${ }^{2}$ Division of Food Quality, West Pomeranian University of Technology, Szczecin, Poland \\ ${ }^{3}$ Lisner Sp. z o.o., Poznań, Poland
}

Tokarczyk G., Bienkiewicz G., Suryn J. 2017. Comparative analysis of the quality parameters and the fatty acid composition of two economically important Baltic fish: cod, Gadus morhua and flounder, Platichthys flesus (Actinopterygii) subjected to iced storage. Acta Ichthyol. Piscat. 47 (3): 249-258.

\begin{abstract}
Background. During ice storage of fish a series of biochemical changes occur at a relatively rapid pace. The changes involve both nitrogen compounds and the lipid fraction. Lipid damage, through hydrolysis and oxidation reactions, can lead to important losses in nutritive value and quality during chilled storage. Oxidised lipids are a source of free radical compounds and highly reactive peroxides. The aim of this study was to assess the quality of two economically valuable species of Baltic fish, especially the quality of lipids, during storage in ice.

Materials and methods. The analysis involved two Baltic fish: cod, Gadus morhua Linnaeus, 1758 - a lean fish (about 1\% of fat in flesh) and flounder, Platichthys flesus (Linnaeus, 1758) - an average-fat fish (about 4\% of fat in flesh). Descriptive testing was used for quality determination of fish and the chemical changes of nitrogen compounds (TVB-N)(Total volatile bases nitrogen) and lipids (PV—peroxide value and AsV—anisidine value) were analysed. Changes of FA (fatty acids) were based on the qualitative interpretation of chromatograms.

Results. In cod, peroxide value reached after 10 days a value of $45.47 \mathrm{mg} \mathrm{O} \cdot 100 \mathrm{~g}^{-1}$ of lipids. In flounder peroxide value reached the maximum of $26.98 \mathrm{mg} \mathrm{O}^{*} \cdot 100 \mathrm{~g}^{-1}$ after 12 days. The initial anisidine values did not differ significantly and remained at a similar level during storage. It was found that the most significant changes involved loss of EPA. After fifteen days flounder lost approximately $6.81 \mathrm{mg}$ of EPA $\cdot \mathrm{g}^{-1}$ of fat (about $10 \%$ of initial amount), whereas cod about $9 \mathrm{mg} \mathrm{EPA} \cdot \mathrm{g}^{-1}$ of fat (about $26.5 \%$ of initial amount). The observed loss of DHA was much lower, in particular in flounder.

Conclusion. Different dynamics of oxidative changes were observed. In cod primary oxidation products increased linearly but in flounder such dynamic growth occurred after 12 days of storage still being almost twice as low as that of cod. No significant differences were observed in the secondary oxidation products between the fish. The level of PUFA and especially the level of EPA and DHA decreased. The loss of PUFA were higher in the lipid fraction of cod than flounder and were respectively about $2 \mathrm{pp}$ and about $0.4 \mathrm{pp}$ for each day of storage. Moreover, the dynamics of loss of EPA was greater than DHA.
\end{abstract}

Keywords: fish quality, shelf life of fish, lipid quality, EPA and DHA changes

\section{INTRODUCTION}

Fish, due to their specific chemical composition and the characteristics of their environment require particularly strict storage conditions. To ensure their best possible quality, captured fish are gutted and cooled in ice. The purpose of such a treatment is to keep their tissues fresh for the longest possible time and to preserve their high nutritional value (Simopoulos 1997). Iced storage is an important preservation method to maintain the quality of fish during handling and storage. However, it could not completely inhibit biochemical reaction and bacteriological activity, which result in affecting odour, flavour, colour, texture, and nutritional values of fish (Gao et al. 2014). Maintaining high quality and safety of stored fish material is a challenge for both the fishermen and the producers. Most often several days pass between catching 
fish and their landing. During ice storage of fish a series of biochemical changes occur at a relatively rapid pace. The changes involve both nitrogen compounds (Huidobro et al. 2001) and the lipid fraction (Widjaja et al. 2009, Saeleaw and Benjakul 2014). Among different mechanisms responsible for fish deterioration during storage on ice, lipid damage, through hydrolysis and oxidation reactions of the lipid fraction, can lead to important losses in nutritive value and quality during chilled storage (Šimat et al. 2015). While changes of nitrogen compounds are accompanied by formation of compounds emitting intense unpleasant odour, in the case of changes in lipid quality, for lean fish in particular, such compounds are formed at a much later stage (Harris and Tall 1994). Lipid oxidation is associated with the development of undesirable odour, especially fishy odour, in fish stored for an extended period of time (Maqsood and Benjakul 2011b, Farvin et al. 2012). Therefore, it is critical to monitor the freshness of the raw material not only by evaluating the quantity of volatile nitrogen compounds (TVB-N) (Gill 1990), but also by assessing the quality of lipids (Gao et al. 2014). The EU regulations (Anonymous 2004) specify that food business operators are to carry out specific checks in order to prevent fishery products, which are unfit for human consumption, from being placed on the market. Those checks also include the total volatile base nitrogen (TVB-N) limits, which are not to be exceeded. Another EU regulation (Anonymous 2008) defines acceptable levels of TVB-N for various families of fish and provides a straightforward answer whether the product is acceptable or not. It is necessary to set levels of TVB-N that are not to be exceeded in the case of certain species categories and to specify the analysis methods to be used. The analysis methods that are scientifically recognised for checking TVB-N should continue to be used as a matter of routine, but a reference method should be specified for use where there is doubt regarding the results or in the event of dispute (Anonymous 2005).

There has been little research on the changes in lipid quality that particularly focuses on lean fish, such as cod, or fish with an average fat content, such as flounder. The majority of the available literature involves research on storage of fat fish, such as trout (Kołakowska et al. 2006b), sardine (Losada et al. 2004), halibut (GuillermRegost et al. 2006), pompano (Gao et al. 2014), or silver carp (Shi et al. 2014). Development of fishy odour in sea bass and red tilapia muscle was primarily associated with lipid oxidation (Thiansilakul at al. 2010). In addition, lipid oxidation induced by lipoxygenase was responsible for a strong fishy odour in silver carp mince (Fu et al. 2009). Moreover, fishy odour in protein hydrolysate caused by lipid oxidation was reported by Yarnpakdee et al. (2012). The processes of hydrolysis and oxidation of lipids are hard to detect with senses, particularly in case of lean fish. These processes are nonetheless a major threat to the quality and safety of raw fish material. Oxidised lipids are a source of free radical compounds and highly reactive peroxides. They can also interact with other components of raw material, such as proteins, causing their denaturation, deterioration of the tissue and the consequent loss of nutritional value (Verma et al. 1995, Kołakowska 2010).

The cod, Gadus morhua Linnaeus, 1758, is one of economically important species of Poland and is also targeted by fisheries fleets of other Baltic countries. The other species, the flounder, Platichthys flesus (Linnaeus, 1758), is either purposely captured in the frames of the fishing quotas allocated by ICES or comes as a bycatch of the cod fishery. In 2017, the ICES Baltic Sea quotas for flounder were $41196 \mathrm{t}$, while for cod $27911 \mathrm{t}$ (Anonymous 2016b, 2016c), although the European Commission has proposed 26515 t (Anonymous 2016d). Cod due to its attractive white colour of flesh, delicacy, and high nutritional value, are often used to produce ready-to-eat products and other high quality fish products, which are well suited for human consumption. Flounder is characterized by white, medium fat, and very delicate flesh. It is quite neutral in flavour, so is ideal for baking, cooking, stewing or grilling, and even smoking.

\section{MATERIALS AND METHODS}

Materials. Analyses were carried out on raw flesh tissue of two species of Baltic fish: cod and flounder. These fish were caught in April and May, respectively on the fishing grounds of the south-western Baltic Sea. After the capture, the fish were gutted and iced in PVC boxes with perforated bottom. Additional portion of ice was placed on top of each batch. The containers were kept at $2 \pm 0.5^{\circ} \mathrm{C}$. The ratio of fish to ice was $1 \div 1$. The gutted fish were placed the gut cavity down. The storage temperature was checked daily and additional ice was added every few days. The fish for assays were randomly selected starting from the day of the assumed death (about $12 \mathrm{~h}$ after capture) which was defined as day 1 , as well as after $3,5,7,10,12$, and 15 days of storage. Each time five gutted fish were selected and two fish of each treatment were subjected to sensory evaluation, while chemical assays were performed on three fish. The fish were filleted and ground with their skin by means of an electric meat grinder with a $2 \mathrm{~mm}$ diameter cutting plate.

Analytical techniques. Descriptive testing was used for quality determination and shelf life studies applying a structured scaling method. Structured scaling gives the panellist an actual scale showing five degrees of intensity: $0=$ fresh seaweed-like smell, $1=$ odourless, $2=$ slight fishy odour, 3 = significant fishy odour, $4=$ strong fishy odour, 5 = totally off odour. A 5-point scale was used as described sensory changes, and an overall impression of odour, was evaluated in an integrated way. Descriptors was carefully selected on the basis of FAO 29 (Huss 1988), and panellists trained following ISO 5496 (Anonymous 2006). Odour tests were conducted on raw samples using five trained assessors. Prior to the evaluation, the panellists were trained three times a week. Each panellist received a different but identically treated pack to sniff. All samples were kept on ice until evaluation. The packs (one portion) were opened and sniffed immediately. The scores of the five assessors were averaged. 
TVB-N (Total volatile bases nitrogen) was determined by Conway and Byrne (1933) method according to the Commission Regulation (EC) No 2074/2005 of 5 December 2005 (Anonymous 2005).

Lipids were extracted from raw tissue with a chloroform-methanol mixture $(1 \div 1 \mathrm{v} / \mathrm{v})$ according to Bligh and Dyer (1959), and extraction was performed twice. The lipid content was determined gravimetrically, by evaporating a defined amount of extract. Peroxide values (PV) of lipids were determined using the thiocyanate technique (Pietrzyk 1958) based on the oxidation of ferrous salt by hydroperoxides and the reaction of ferric salts with potassium isothiocyanate. The red ferric complexes formed were determined spectrophotometrically. The results are expressed as $\mathrm{mg}$ active oxygen $\cdot 100 \mathrm{~g}^{-1}$ lipids. Anisidine value (AsV) were determined according to ISO standard (Anonymous 2016a). The obtained PV and AsV were approximated with curves that most accurately represented the empirical data. For each curve, a chisquared $\left(v^{2}\right)$ value was given, which represented the curve fitting to the empirical values.

Fatty acids analysis. Fatty acid methyl esters (FAMEs) were obtained from the tissue by alkaline hydrolysis of extract of lipids with $0.5 \mathrm{M} \mathrm{mol} \cdot \mathrm{dm}^{-3} \mathrm{~mol} \cdot \mathrm{L}^{-1}$ sodium methylate $\left(\mathrm{CH}_{3} \mathrm{ONa}\right)$. Details of the analysis have been described in an earlier study (Domiszewski and Bienkiewicz 2010). Next, the FAMEs were separated using a gas chromatography apparatus, coupled with a mass spectrometer (Agillent Technologies 7890A) and equipped with a split/splitless type injector. Conditions of FAMEs separation were as follows: column SPTM 2560, catalogue No. 24056; carrier gas (helium) at a constant flow rate of $1.2 \mathrm{~cm}^{3} \cdot \mathrm{min}^{-1}$; split $1 \div 50$; injector temperature: $220^{\circ} \mathrm{C}$; detector temperature: $220^{\circ} \mathrm{C}$; programmed furnace temperature: $140^{\circ} \mathrm{C}(5 \mathrm{~min})$ increased to $240^{\circ} \mathrm{C}$ at a rate of $4^{\circ} \mathrm{C} \cdot \mathrm{min}^{-1}$; analysis time: $45 \mathrm{~min}$. The qualitative interpretation of chromatograms was based on the comparison of retention times and mass spectra of the particular FAMEs of the sample with those of analogous FAME standards by Sigma company (Lipid Standard). As an internal standard, nonadecanoic acid methyl ester was used.

Statistical analysis. Numbers presented in tables are the mean values of triplicate analysis. The statistical analysis was based on the one-way analysis of variance, homogeneous groups were formed according to the Duncan test for $P=0.05$. The data were statistically analysed using STATISTICA (data analysis software system) 2010 version by StatSoft Inc.

\section{RESULTS}

Sensory analysis. Initially, both fish received the highest possible score during the sensory analysis. As the storage progressed, the differences in the assessed quality between the fish started to become apparent (Fig. 1). Before day 5 of storage, these differences were statistically insignificant, and the rates of odour degradation were very similar. Only as late as between day 7 and 15 a significant change in the dynamics of odour degradation was observed. After
10 days of storage, the neutral odour score for flounder was 3.75, whereas for cod it was lower than 1.75 - a result below the acceptance level.

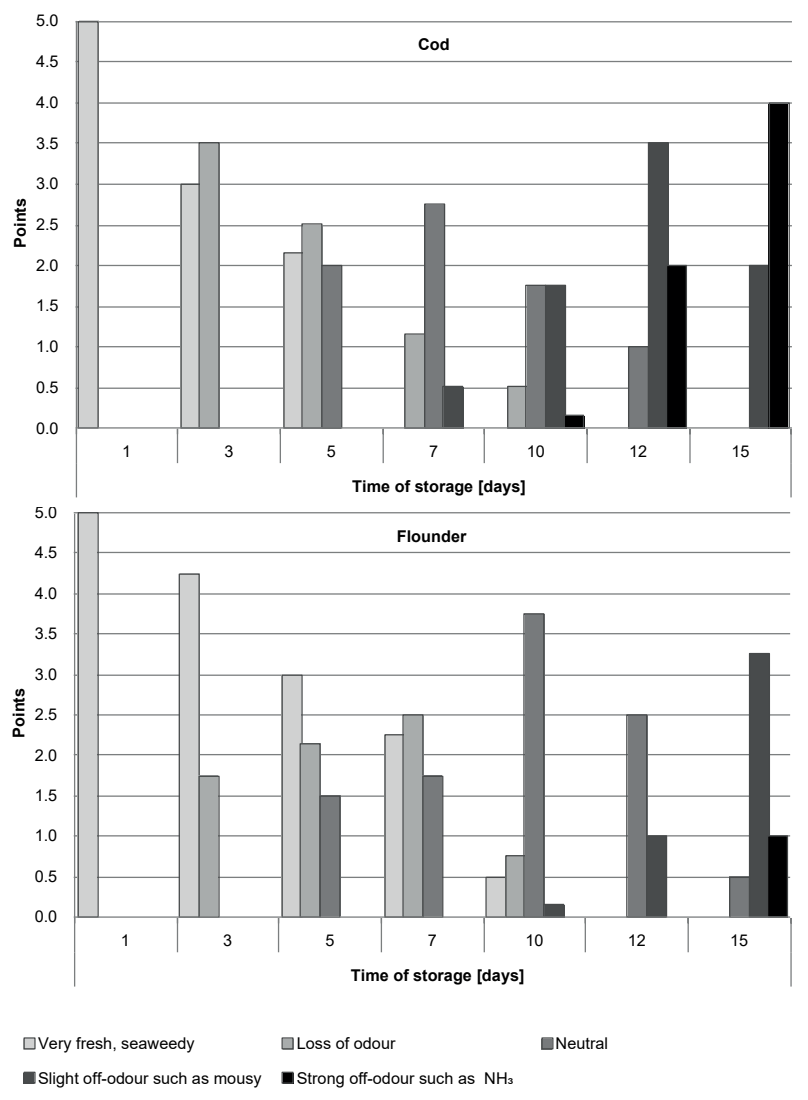

Fig. 1. The results of the odour sensory evaluation of flounder and cod stored in ice for 15 days

TVB-N changes. The changes in the sensory evaluation outcomes correlated with the changes in nitrogen compounds expressed as TVB-N. Table 1 shows the changes in TVB-N during storage. Initially the TVB-N values of cod flesh were lower than in flounder flesh till day 7 day of storage. Since day 10, TVB-N values of flounder samples were lower $(P<0.05)$ and the amounts of TVB-N at day 10 of storage were $13.48 \mathrm{mg} \cdot 100 \mathrm{~g}^{-1}$ and $16.48 \mathrm{mg} \cdot 100 \mathrm{~g}^{-1}$, respectively. This value was not higher than $30 \mathrm{mg} \cdot 100 \mathrm{~g}^{-1}$ for flounder and $40 \mathrm{mg} \cdot 100 \mathrm{~g}^{-1}$ for cod during the storage time.

Qualitative changes in lipids. Table 1 shows fat content in the flesh of two species under comparison. The content of fat was evaluated simultaneously with other parameters for the period of storage in ice. The compared species differed substantially in terms of fat content.

Figure 2 shows the changes in primary products of lipid oxidation expressed as peroxide value. In the case of cod, peroxide value reach, after 10 days, a value of 45.47 $\mathrm{mg} \mathrm{O}^{*} \cdot 100 \mathrm{~g}^{-1}$ of lipids. However, for flounder, after day 12 of storage, peroxide value reached the maximum of $26.98 \mathrm{mg} \mathrm{O}^{*} \cdot 100 \mathrm{~g}^{-1}$ on day 10 , while still being almost twice as low as that of cod.

Figure 3 shows the changes in secondary products of lipid oxidation expressed as anisidine value. No significant 
differences were observed in the amounts of these products between the compared species during their storage in ice. The initial anisidine values did not differ significantly and amounted to 1.55 for cod and 1.12 for flounder. These values remained at a similar level for the first 7 days of storage. After day 7, AsV dramatically increased, reaching on day 15, the values14.01 and 10.79 for flounder and cod, respectively.

Changes in fatty acid composition. A comparison of the content of fatty acids (Table 2 and 3 ) of the analysed species revealed that cod lipids contained twice as much polyunsaturated fatty acids (PUFA) than flounder

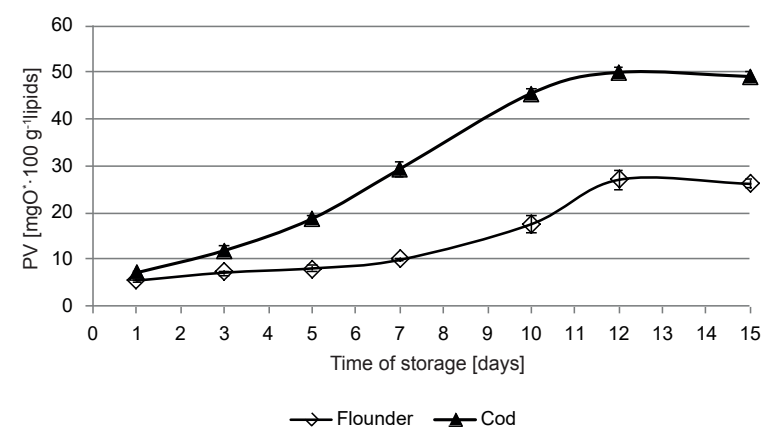

Fig. 2. Changes in peroxide value (PV) in cod and flounder during storage in ice for 15 days $(n=5)$ lipids. Significant differences were also observed in the amount and percentage of the particularly valuable and nutritionally essential fatty acids: eicosapentaenoic (EPA) and docosahexaenoic (DHA). The amounts of these acids for cod were respectively 33.54 and $83.32 \mathrm{mg} \cdot \mathrm{g}^{-1}$ of fat, whereas for flounder these numbers were reversed: the amount of EPA was $67.54 \mathrm{mg} \cdot \mathrm{g}^{-1}$ of fat, and for DHA it was $42.77 \mathrm{mg} \cdot \mathrm{g}^{-1}$ of fat.

It was found that for flounder the loss of SFA, MUFA, and PUFA were very similar $(5.6 \%, 4 \%$, and $5.9 \%$, respectively) during the storage time but for cod the losses depended on the group of fatty acids. In case

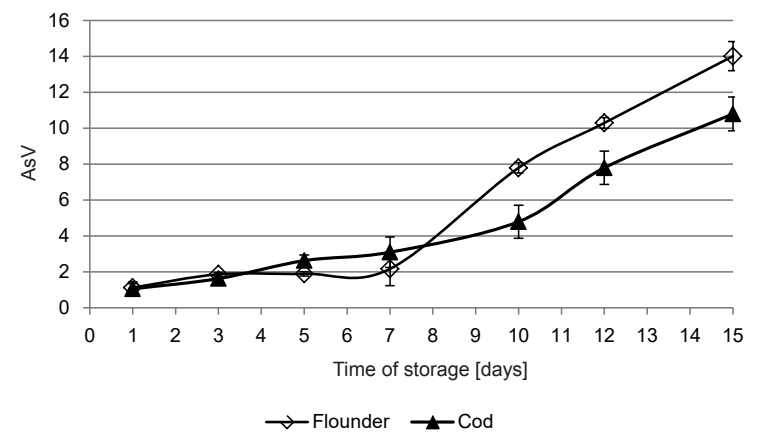

Fig. 3. Changes in anisidine value (AsV) in cod and flounder during storage in ice for 15 days $(n=5)$

Table 1 Changes in lipid, water, and total volatile bases nitrogen (TVB-N) in cod and flounder during storage in ice for 15 days $(n=5)$

\begin{tabular}{|c|c|c|c|c|c|c|}
\hline \multirow[b]{2}{*}{ Day of storage } & \multicolumn{3}{|c|}{ Flounder } & \multicolumn{3}{|c|}{ Cod } \\
\hline & $\begin{array}{c}\text { Water } \\
{[\%]}\end{array}$ & $\begin{array}{c}\text { TVB-N } \\
{\left[\mathrm{mg} \cdot 100 \mathrm{~g}^{-1}\right]}\end{array}$ & $\begin{array}{l}\text { Fat } \\
{[\%]}\end{array}$ & $\begin{array}{c}\text { Water } \\
{[\%]}\end{array}$ & $\begin{array}{c}\text { TVB-N } \\
{\left[\mathrm{mg} \cdot 100 \mathrm{~g}^{-1}\right]}\end{array}$ & $\begin{array}{l}\text { Fat } \\
{[\%]}\end{array}$ \\
\hline 1 & $73.44 \pm 0.08^{\mathrm{a}}$ & $4.11 \pm 0.11 \mathrm{aA}$ & $4.29 \pm 0.11^{\mathrm{a}}$ & $77.44 \pm 0.11^{\mathrm{a}}$ & $3.42 \pm 0.31 \mathrm{aB}$ & $1.17 \pm 0.05^{\mathrm{a}}$ \\
\hline 3 & $73.14 \pm 0.09^{\mathrm{a}}$ & $5.88 \pm 0.26^{\mathrm{bA}}$ & $4.28 \pm 0.07^{\mathrm{a}}$ & $77.15 \pm 0.12^{\mathrm{a}}$ & $5.12 \pm 0.48^{\mathrm{bA}}$ & $1.14 \pm 0.07^{\mathrm{a}}$ \\
\hline 5 & $72.64 \pm 0.10^{\mathrm{a}}$ & $7.81 \pm 0.47 \mathrm{cA}$ & $4.55 \pm 0.02^{\mathrm{a}}$ & $77.43 \pm 0.13^{\mathrm{a}}$ & $5.12 \pm 0.49 \mathrm{bB}$ & $1.14 \pm 0.08^{\mathrm{a}}$ \\
\hline 7 & $72.08 \pm 0.10^{\mathrm{a}}$ & $10.54 \pm 0.27^{\mathrm{dA}}$ & $4.65 \pm 0.21^{\mathrm{a}}$ & $76.42 \pm 0.83^{\mathrm{ab}}$ & $9.86 \pm 0.33^{\mathrm{cA}}$ & $1.28 \pm 0.11^{\mathrm{a}}$ \\
\hline 10 & $71.94 \pm 0.51^{\mathrm{ab}}$ & $13.48 \pm 1.94 \mathrm{eA}$ & $5.02 \pm 0.08^{\mathrm{b}}$ & $75.01 \pm 0.94^{\mathrm{b}}$ & $16.48 \pm 2.52 \mathrm{~dB}$ & $1.67 \pm 0.18^{\mathrm{b}}$ \\
\hline 12 & $70.98 \pm 0.32^{b}$ & $16.82 \pm 0.95 \mathrm{fA}$ & $4.92 \pm 0.09^{b}$ & $75,21 \pm 0.95^{\mathrm{bc}}$ & $29.95 \pm 1.06^{\mathrm{eB}}$ & $1.27 \pm 0.39^{\mathrm{a}}$ \\
\hline 15 & $70.64 \pm 0.63^{b}$ & $27.55 \pm 0.76^{\mathrm{gA}}$ & $5.02 \pm 0.23^{b}$ & $73.01 \pm 1.06^{\mathrm{c}}$ & $38.88 \pm 2.07 \mathrm{fB}$ & $1.29 \pm 0.30^{\mathrm{a}}$ \\
\hline
\end{tabular}

Changes in fatty acid composition in flounder during 15-day storage in ice $(n=3)$

\begin{tabular}{lccccccc}
\hline \multirow{2}{*}{ Fatty acid } & \multicolumn{7}{c}{ Fatty acid content [mg acid $\cdot \mathrm{g}^{-1}$ of lipid] } \\
\cline { 2 - 8 } & Day 1 & Day 3 & Day 5 & Day 7 & Day 10 & Day 12 & Day 15 \\
\hline SFA & $296.67 \pm 11.14$ & $290.82 \pm 11.96$ & $290.77 \pm 12.04$ & $289.65 \pm 21.08$ & $289.40 \pm 31.22$ & $280.63 \pm 22.48$ & $280.01 \pm 13.52$ \\
MUFA & $446.18 \pm 11.92$ & $437.22 \pm 11.55$ & $436.82 \pm 11.15$ & $436.23 \pm 21.06$ & $436.03 \pm 22.63$ & $429.85 \pm 14.06$ & $428.12 \pm 15.09$ \\
PUFA & $179.25 \pm 11.77$ & $175.81 \pm 11.91$ & $174.98 \pm 1.85$ & $174.72 \pm 11.19$ & $171.78 \pm 11.78$ & $170.85 \pm 12.51$ & $168.74 \pm 22.96$ \\
EPA & $67.94 \pm 0.11^{\mathrm{a}}$ & $66.60 \pm 0.09^{\mathrm{b}}$ & $66.49 \pm 0.25^{\mathrm{b}}$ & $66.34 \pm 0.16^{\mathrm{b}}$ & $64.57 \pm 0.14^{\mathrm{c}}$ & $62.81 \pm 0.22^{\mathrm{d}}$ & $61.05 \pm 0.88^{\mathrm{e}}$ \\
DHA & $42.77 \pm 0.19^{\mathrm{a}}$ & $41.92 \pm 0.06^{\mathrm{b}}$ & $41.52 \pm 0.43^{\mathrm{b}}$ & $41.76 \pm 0.09^{\mathrm{b}}$ & $41.41 \pm 0.04^{\mathrm{b}}$ & $40.06 \pm 0.43^{\mathrm{c}}$ & $40.71 \pm 0.36^{\mathrm{c}}$ \\
Total fatty acids & 922.11 & 903.86 & 902.57 & 900.61 & 897.23 & 881.33 & 876.87 \\
\hline
\end{tabular}

SFA = saturated fatty acids, MUFA = monounsaturated fatty acids, PUFA = polyunsaturated fatty acids, EPA = eicosapentaenoic acid, DHA = docosahexaenoic acid; Superscript values represented by the same lower-case letters in row are not significantly different from each other with $P \leq 0.05$; superscript values represented by the same low-case letters in column are not significantly different from each other with $P \leq 0.05$; superscript values represented by the same capital letters in rows (for the same parameter between fish) are not significantly different from each other with $P \leq 0.05$. 
of SFA the loss was about $6 \%$ of initial amount of this group of fatty acids. Slightly higher loss was found for MUFA, amounting to $9 \%$, and the biggest loss was found for PUFA (about 26\%) (Table 2 and 3). Furthermore, for both flounder and cod, the most significant changes involved loss of EPA during storage. Flounder, after 15 days of storage in ice, lost approximately $6.81 \mathrm{mg}$ of this acid, whereas for cod the EPA loss amounted to about $9 \mathrm{mg}$. The observed loss of DHA was much lower, in particular in case of flounder. This loss in case of cod was more noticeable, but still much lower than the loss of EPA, with the amount being twice as low (Table 2 and 3 ).

\section{DISCUSSION}

The main objective of this study was to analyse the changes in lipid quality of lean fish and fish with average fat content, caught in the same body of water and during the same fishing period, and stored in ice for 15 after gibbing. It was demonstrated in the presently reported study that if fish such as cod or flounder are stored in ice, their lipid oxidation level substantially rises throughout the period of storage in ice, whereas the level of valuable nutritional fatty acids EPA and DHA decreases. Different dynamics of oxidative changes were observed for flounder and for cod. Moreover, differences were found between the compared species in the dynamics of change in the amount of EPA and DHA - the loss of EPA was greater than DHA during the storage of the fish in ice.

Sensory analysis. The sensory quality (odour) of the analysed fish varied depending on the time of storage in ice. The garlic- and sour smell of the fish were the reason of the difference in sensory quality. Cod, on day 12 of storage, revealed noticeable fishy and ammonia smellan indicator of advanced decomposition of nucleotides (Tanimoto et al. 1999) and decomposition of nitrogen compounds, in particular reduction of TMAO (Antoine et al. 2002). Such changes are typical for active marine fish such as cod (Wheaton and Lawson 1985). The change in flounder smell was noticeable to a much lesser extent. After 12 days of storage, a fishy smell was noticeable, with no ammonia odour. This may be linked to a significantly lower activity of endogenous enzymes of flounder, whose activity, as a benthic fish, is much lower compared to cod (Fik 1972).
There was a relation between the sensory and the nitrogen compounds expressed as TVB-N. This index is commonly used to assess the quality of fresh fish (Sikorski 2004, Howgate 2010, García-Sato et al. 2013), and frozen fish (Sikorski 2004) as well as fish products (Kołakowski et al. 2004). The TVB-N and TMA-N are produced by bacterial spoilage and endogenous enzymes. The amount of TVB-N in fresh fish is about $10 \mathrm{mg} \cdot 100 \mathrm{~g}^{-1}$ (Metin et al. 2001, Koral et al. 2009) and during cold storage can increase several times in relation to the amount in fresh material (Koral et al. 2009). According to EU regulations (Anonymous 2008), the maximum concentration of volatile basic nitrogen (TVB-N) in fish products should not exceed $35 \mathrm{mg} \cdot 100 \mathrm{~g}^{-1}$ of tissue. Between 10 and $15 \mathrm{mg}$ of TMA-N $\cdot 100 \mathrm{~g}^{-1}$ of fish product is generally accepted to be the upper limit of its suitability for consumption by people (Huss 1988).

Transformations of nitrogen compounds and nucleotides significantly affect sensory acceptability of raw fish and determine its usefulness. However, during cold storage, apart from the transformations of nitrogen compounds and nucleotides, also lipids undergo qualitative change that affects the final quality of the fish. An analysis of this phenomenon is the main objective of this study.

Qualitative changes in lipids. There was a statistically insignificant increase in the extractability of fat from muscle tissue versus storage time. It was closely correlated with the loss of water. It was assumed that the different fat content and completely different living environments of the compared species significantly contributed to the dynamics and type of changes in lipid quality.

Different growth rates of peroxide value were observed (Fig. 2). For cod, peroxide value increased linearly with storage time. However, for flounder, such dynamic growth occurred as late as after day 12 of storage. Similar studies were conducted for cod by Aubourg and Medina (1999) who assessed the effects of freeze-storage at two different temperatures on the changes in lipid quality. These authors found a strong correlation between time and temperature of storage, and growth rate of primary products of lipid oxidation in cod flesh. Significantly greater growth rate of primary oxidation products in comparison with flounder may be a result of different composition of lipids of these two species. For cod, a lean fish, the dominant faction are

Table 3

Changes in fatty acid composition in cod during 15-day storage in ice $(n=3)$

\begin{tabular}{lccccccc}
\hline \multirow{2}{*}{ Fatty acid } & \multicolumn{7}{c}{ Fatty acid content [mg acid $\cdot \mathrm{g}^{-1}$ of lipid] } \\
\cline { 2 - 8 } & Day 1 & Day 3 & Day 5 & Day 7 & Day 10 & Day 12 & Day 15 \\
\hline SFA & $225.88 \pm 11.05$ & $222.08 \pm 11.19$ & $221.04 \pm 21.15$ & $213.25 \pm 21.77$ & $212.74 \pm 11.14$ & $212.43 \pm 21.12$ & $212.05 \pm 26.17$ \\
MUFA & $375.23 \pm 22.36$ & $373.54 \pm 31.14$ & $371.36 \pm 31.63$ & $366.83 \pm 21.94$ & $360.74 \pm 11.98$ & $358.09 \pm 31.01$ & $341.26 \pm 36.19$ \\
PUFA & $330.59 \pm 10.23$ & $330.41 \pm 21.14$ & $325.96 \pm 21.27$ & $319.74 \pm 12.19$ & $301.95 \pm 21.17$ & $276.45 \pm 28.19$ & $243.12 \pm 8.84$ \\
EPA & $33.54 \pm 0.69^{\mathrm{a}}$ & $31.49 \pm 1.01^{\mathrm{b}}$ & $29.46 \pm 0.36^{\mathrm{c}}$ & $28.47 \pm 0.72^{\mathrm{d}}$ & $27.48 \pm 0.13^{\mathrm{e}}$ & $25.96 \pm 1.02^{\mathrm{f}}$ & $24.66 \pm 0.58^{\mathrm{f}}$ \\
DHA & $83.32 \pm 1.09^{\mathrm{a}}$ & $81.23 \pm 1.14^{\mathrm{b}}$ & $80.12 \pm 0.85^{\mathrm{b}}$ & $79.57 \pm 0.09^{\mathrm{c}}$ & $78.41 \pm 0.74^{\mathrm{d}}$ & $78.26 \pm 1.33^{\mathrm{d}}$ & $76.11 \pm 1.03^{\mathrm{e}}$ \\
Total fatty acids & 931.72 & 926.04 & 918.36 & 899.84 & 875.43 & 846.88 & 796.43 \\
\hline
\end{tabular}

SFA = saturated fatty acids, MUFA = monounsaturated fatty acids, PUFA = polyunsaturated fatty acids, EPA = eicosapentaenoic acid, $\mathrm{DHA}=$ docosahexaenoic acid; superscript values represented by the same lower-case letters in row are not significantly different from each other with $P \leq 0.05$. 
phospholipids, whose composition includes a large amount of polyunsaturated fatty acids, which causes such lipids to undergo oxidation processes earlier than others and at the greatest rate (Kołakowska 2010). On the other hand, flounder flesh contains more fat, its lipids are composed mainly of acylglycerols that are first hydrolysed and then undergo oxidation. This is also confirmed by the analyses carried out within this study, which revealed faster increase of acid value for flounder than for cod (Fig. 4).

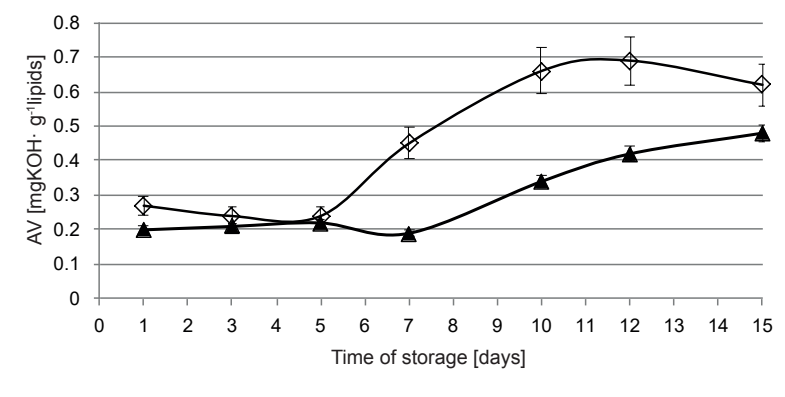

$\sim$ Flounder $\rightarrow$ Cod

Fig. 4. Changes in acid value (AV) in cod and flounder during storage in ice for 15 days $(n=5)$

Tissue enzymes such as lipoxygenase and lipase may be another factors contributing to the rapid increase in the amount of oxidation products and free fatty acids, for fresh fish, not subjected to thermal treatment, these enzymes are not inactivated and may have a substantial impact on the changes in lipid quality (Wang et al. 1991). Lipoxygenase may play a special role in the lipid oxidation process - it is a catalyst for oxidation of free or esterified fatty acids (Baysal and Demirdöven 2007, Kołakowska and Bartosz 2010). Pro-oxidants present in muscle tissue and the parts of viscera remaining after gibbing, which were washed out by the melting ice might be other factors affecting the oxidation potential of the compared fish species. In this case myoglobin might be the main pro-oxidant (Undeland et al. 2004, Neira et al. 2011). It plays an important role in oxidation of muscle lipids, especially in the presence of peroxides and hydroperoxides, in which case it can be converted to ferryl myoglobin, thus being the main source of haematin and free ion iron. These compounds may not only trigger but also accelerate the process of lipid oxidation (Min and Ahn 2005). Significant impact of bleeding ice-stored fish on the process of lipid oxidation was demonstrated in a study by Maqsood and Benjakul (2011a), who conducted research on bled and un-bled Asian seabass stored 15 days in ice.

Anisidine value indicates the number of secondary lipid oxidation products (aldehydes, ketones) formed mainly as a result of degradation of peroxides (Aidos et al. 2002, Kamal-Eldin and Pokorný 2005). Therefore, it is possible that in the case of storing fish in ice for a relatively short period and at a temperature of approximately $2{ }^{\circ} \mathrm{C}$, the secondary oxidation can be for all intents and purposes ignored. This period is too short and the temperature too low for significant degradation of primary oxidation products and accumulation of aldehydes, in particular malonic aldehyde. This problem is more noticeable and emphasised in case of thermal treatment, especially if heat is applied to muscle tissue. A study by Domiszewski (2012, 2013) carried out on herring and Baltic sprat, and by Regulska-Ilow and Ilow (2002), carried out on herring, showed that applying such forms of treatment as boiling, frying or grilling results in a decrease in the amount of primary oxidation products and an increase in the amount of secondary oxidation products. TBA index (thiobarbituric acid index) is another indicator of formation of malonic aldehyde, also as a result of thermal treatment. An increase in TBA index was observed in a study by Tokur (2007), who analysed trout flesh, by Turhan et al. (2011) for anchovy, and by Domiszewski (2013) for fragmented muscle tissue of heated and cold-stored Baltic herring. It should be noted that this issue is far more pronounced for oily fish (Chaijan et al. 2005) and fish oils (Aidos et al. 2002) than for lean fish (cod) and fish with a mean fat content (flounder).

Changes in fatty acid composition. This different fatty acid composition for the analysed species of fish caught in the same body of water and during the same fishing period can be attributed to extremely different living environment, availability of food, competition for food, as well as the differences related to the annual development cycle of fish (lipid metabolism) (Kołakowska et al. 2006a).

When comparing the quantitative changes in the fatty acid during the storage of the fish in ice, the authors focused exclusively on the analysis of changes in EPA and DHA, acids that are commonly regarded as the most labile and susceptible to oxidation (Kołakowska et al. 2006b, Kołakowska 2010, Domiszewski 2013). It was shown that the level of SFA, MUFA, and PUFA and especially the level of valuable nutritional fatty acids EPA and DHA decreases during storage cod or flounder in ice. Greater reduction of these groups of fatty acids were in lipid fraction of cod than flounder. In flounder the loss of SFA, MUFA, and PUFA were very similar (about 5\%) during the storage time but in cod the losses depended on the group of fatty acids and the biggest loss was found in PUFA (about 26\%). The loss of PUFA were higher in the lipid fraction of cod than flounder and were respectively about 2 percentage points and about 0.4 percentage point for each day of storage in ice. Very similar results were obtained by Saeleaw and Benjakul (2014) except for SFA changes. Authors demonstrated similar changes of MUFA and PUFA during storage of sea bass in ice. MUFA and PUFA decreased during storage time, while SFA increased.

Furthermore it was found that, for both flounder and cod, the most significant changes involved loss of EPA during storage. It can be concluded that the differences in the amount of loss between these acids during storage in ice are reflected in the dynamics of oxidative changes and the formation of lipid oxidation products, as shown in Fig. 2. The relation between the loss of the total EPA and DHA and the increase in fish lipid oxidation was observed, among others, by Jittrepotch et al. (2006), based on an analysis of cooked and fridge-stored sardine. Additionally, Domiszewski (2013) proved the existence such relation 
with regard to heating the tissue of Baltic herring and sprat. A study conducted by Kołakowska et al. (2006a) on whole and eviscerated trout stored in ice for 15 days showed a significant change in the percentage of these acids in the overall amount of fatty acids. The greatest losses of these acids were observed on day 7 and 14 of storage. Additionally, Sohn and Ohshima (2010) demonstrated that EPA and DHA losses occur in case of tuna stored in ice. The losses of these acids were significantly higher in dark muscles than in white. The above allows to indirectly prove that myoglobin affects lipid oxidation and, consequently, that there is a correlation between the oxidation level and the loss of these fatty acids.

An important conclusion for the issue of iced storage of fish is the importance of evaluation of their lipids quality. This also includes lean fish, because of rapid increase in oxidation products, and the consequent lowering of the nutritional value of such fish. The scarcity of the related research can be attributed to the lack of legal regulations on the quality (oxidation level) of fish and fish-oil lipids. During iced storage, the flesh lipid oxidation level of such fish as cod or flounder substantially rises, whereas the level of PUFA and especially the level of valuable nutritional fatty acids EPA and DHA decreases. Moreover, the loss of EPA was greater than DHA during the storage of the fish in ice. Furthermore different dynamics of oxidative changes were observed for these fish. For cod, peroxide value increased linearly with storage time, but for flounder, such dynamic growth occurred as late as after day 12 of storage. However no significant differences were observed in the amounts of anisidine value between the compared species during their storage in ice.

Nevertheless, as shown by the work of the European Parliament within the FAO/WHO, a regulation defining quality parameters for fish oils is being drafted and should be published in the near future.

\section{REFERENCES}

Aidos I., Lourenço S., Van der Padt A., Luten J.B., Boom R.M. 2002. Stability of crude herring oil produced from fresh byproducts: Influence of temperature during storage. Journal of Food Science 67 (9): 3314-3320.

DOI: $10.1111 / \mathrm{j} .1365-2621.2002 . t b 09585 . \mathrm{x}$

Anonymous 2004. Regulation (EC) No 853/2004 of the European Parliament and of the Council of 29 April 2004 laying down specific hygiene rules for food of animal origin. Official Journal of the European Union L 139/55.

Anonymous 2005. Commission Regulation (EC) No 2074/2005 of 5 December 2005 laying down implementing measures for certain products under Regulation (EC) No 853/2004 of the European Parliament and of the Council and for the organization of official controls under Regulation (EC) No 854/2004 of the European Parliament and of the Council and Regulation (EC) No 882/2004 of the European Parliament and of the Council, derogating from Regulation (EC) No 852/2004 of the
European Parliament and of the Council and amending Regulations (EC) No 853/2004 and (EC) No 854/2004. Official Journal of the European Union L 338/27.

Anonymous 2006. ISO 5496:2006 Sensory analysisMethodology_-Initiation and training of assessors in the detection and recognition of odours. International Organisation for Standardisation, Geneva, Switzerland.

Anonymous 2008. Commission Regulation (EC) No $1022 / 2008$ of 17 October 2008 amending Regulation (EC) No 2074/2005 as regards the total volatile basic nitrogen (TVB-N) limits. Official Journal of the European Union L 277/18.

Anonymous 2016a. ISO 6885:2016 Animal and vegetable fats and oils-Determination of anisidine value. International Organisation for Standardisation, Geneva, Switzerland.

Anonymous 2016b. Cod (Gadus morhua) in subdivisions 22-24, western Baltic stock (western Baltic Sea). In: Report of the ICES Advisory Committee, 2016. ICES Advice 2016, Book 8, Section 8.3.4: 1-12. http://www.ices.dk/sites/pub/Publication\%20Reports/ Advice/2016/2016/cod-2224.pdf

Anonymous 2016c. Cod (Gadus morhua) in subdivisions 24-32 (eastern Baltic stock) (eastern Baltic Sea). In: Report of the ICES Advisory Committee, 2016. ICES Advice 2016, Book 8, Section 8.3.5: 1-8. http://www.ices.dk/sites/pub/Publication\%20Reports/ Advice/2016/2016/cod-2532.pdf

Anonymous 2016d. EU total allowable catches (TACs) in the Baltic Sea for 2017. Council of the European Union. http://www.consilium.europa.eu/pl/press/pressreleases/2016/10/10-baltic-sea-quotas/

Antoine F.R., Wei C.I., Otwell W.S., Sims C.A., Littell R.C., Hogle A.D., Marshall M.R. 2002. TVB-N correlation with odor evaluation and aerobic plate count in mahi-mahi (Coryphaena hippurus). Journal of Food Science 67 (9): 3210-3214.

DOI: 10.1111/j.1365-2621.2002.tb09567.x

Aubourg S.P., Medina I. 1999. Influence of storage time and temperature on lipid deterioration during cod (Gadus morhua) and haddock (Melanogrammus aeglefinus) frozen storage. Journal of the Science of Food and Agriculture 79 (13): 1943-1948.

DOI: 10.1002/(SICI)1097-0010(199910)79:13<1943::AIDJSFA461>3.0.CO;2-J

Baysal T., Demirdöven A. 2007. Lipoxygenase in fruits and vegetables: A review. Enzyme and Microbial Technology 40 (5): 491-496.

DOI: $10.1016 /$ j.enzmictec.2006.11.025

Bligh E.G., Dyer W.J. 1959. A rapid method for total lipid extraction and purification. Canadian Journal of Biochemistry and Physiology 37 (8): 911-917. DOI: 10.1139/o59-099

Chaijan M., Benjakul S., Visessanguan W., Faustman C. 2005. Changes of pigments and colours in sardine (Sardinella gibbosa) and mackerel (Rastrelliger kanagurta) muscle during ice storage. Food Chemistry 93 (4): 607-617.

DOI: 10.1016/j.foodchem.2004.10.035 
Conway E.J., Byrne A. 1933. An absorption apparatus for the micro-determination of certain volatile substances. I. The micro-determination of ammonia. Biochemical Journal 27 (2): 419-429.

Domiszewski Z. 2012. Effects of heating temperature on the quality of lipids during refrigerated storage of heated muscle tissue of Baltic herring (Clupea harengus membras). Folia Pomeranae Universitatis Technologiae Stetinensis; seria Agricultura Alimentaria Piscaria et Zootechnica 300 (24): 43-56.

Domiszewski Z. 2013. Effect of heating fatty fish: Baltic herring (Clupea harengus membras), European sprat (Sprattus sprattus) and rainbow trout (Oncorhynchus mykiss) on lipid oxidation and contents of eicosapentaenoic and docosahexaenoic acids. International Journal of Food Science and Technology 48 (4): 786-793.

DOI: $10.1111 /$ ijfs. 12028

Domiszewski Z., Bienkiewicz G. 2010. Determining fish fatty acid composition: a comparison of preparation fatty acid metyl esters direct and AOAC methods. Folia Pomeranae Universitatis Technologiae Stetinensis; seria Agricultura Alimentaria Piscaria et Zootechnica 281 (16): 19-30.

Farvin K.H.S., Grejsen H.D., Jacobsen C. 2012. Potato peel extract as a natural antioxidant in chilled storage of minced horse mackerel (Trachurus trachurus): Effect on lipid and protein oxidation. Food Chemistry 131 (3): 843-851.

DOI: $10.1016 /$ j.foodchem.2011.09.056

Fik M. 1972. Activity of muscular cathepsins of some marine fishes. Acta Ichthyologica et Piscatoria 2 (2): 105-111. DOI: 10.3750/AIP1972.02.2.13

Fu X., Xu S., Wang Z. 2009. Kinetics of lipid oxidation and off-odor formation in silver carp mince: The effect of lipoxygenase and hemoglobin. Food Research International 42 (1): 85-90.

DOI: 10.1016/j.foodres.2008.09.004

Gao M., Feng L., Jiang T., Zhu L., Fu L, Yuan D., Li J. 2014. The use of rosemary extract in combination with nisin to extend the shelf life of pompano (Trachinotus ovatus) fillet during chilled storage. Food Control 37: 1-8.

DOI: 10.1016/j.foodcont.2013.09.010

García-Soto B., Aubourg S.P., Calo-Mata P., BarrosVelázquez J. 2013. Extension of the shelf life of

chilled hake (Merluccius merluccius) by a novel icing medium containing natural organic acids. Food Control 34 (2): 356-363.

DOI: $10.1016 /$ j.foodcont.2013.05.007

Gill T.A. 1990. Objective analysis of seafood quality. Food Reviews International 6 (4): 681-714.

DOI: $10.1080 / 87559129009540899$

Guillerm-Regost C., Haugen T., Nortvedt R., Carlehög M., Lunestad B.T., Kiessling A., Røra A.M.B. 2006. Quality characterization of farmed Atlantic halibut during ice storage. Journal of Food Science 71 (2): 83-90.

DOI: 10.1111/j.1365-2621.2006.tb08926.x

Harris P., Tall J. 1994. Substrate specificity of mackerel flesh lipopolygenase. Journal of Food Science 59 (3): 504-506. DOI: 10.1111/j.1365-2621.1994.tb05548.x

Howgate P. 2010. A critical review of total volatile bases and trimethylamine as indices of freshness of fish. Part 2. Electronic Journal of Environmental, Agricultural and Food Chemistry 9 (1): 58-88.

Huidobro A., Mendes R., Nunes M. 2001. Slaughtering of gilthead seabream (Sparus aurata) in liquid ice: Influence on fish quality. European Food Research Technology 213 (4-5): 267-272.

DOI: $10.1007 / \mathrm{s} 002170100378$

Huss H.H. 1988. Fresh fish-quality and quality changes; A training manual prepared for the FAO/ DANIDA Training Programme on Fish Technology and Quality Control. FAO Fisheries Series No 29. FAO and Danish International Development Agency, Rome.

Jittrepotch N., Ushio H., Ohshima T. 2006. Effects of EDTA and a combined use of nitrite and ascorbate on lipid oxidation in cooked Japanese sardine (Sardinops melanostictus) during refrigerated storage. Food Chemistry 99 (1): 70-82.

DOI: 10.1016/j.foodchem.2005.07.021

Kamal-Eldin A., Pokorný J. 2005. Lipid oxidation products and methods used for their analysis. Pp. 1-8. In: Kamal-Eldin A., Pokorný J. (eds.) Analysis of lipid oxidation. AOCS Press, Champaign, IL, USA.

Kolakowska A. 2010. Fish lipids. Pp. 273-312. In: Sikorski Z.E., Kołakowska A. (eds.). Chemical, biological, and functional aspects of food lipids. CRC Press, Boca Raton, FL, USA.

Kolakowska A., Bartosz G. 2010. Antioxidants. Pp. 185-210. In: Sikorski Z.E., Kołakowska A. (eds.) Chemical, biological, and functional aspects of food lipids. CRC Press, Boca Raton, FL, USA.

Kolakowska A., Domiszewski Z., Bienkiewicz G. 2006a. [Chapter IV] Effects of biological and technological factors on the utility of fish as a source of n-3 PUFA. Pp. 83-107. In: Teale M.C. (ed.) Omega 3 fatty acid research. Nova Science Publishers.

Kołakowska A., Zienkowicz L., Domiszewski Z., Bienkiewicz G. 2006b. Lipid changes and sensory quality of whole- and gutted rainbow trout during storage in ice. Acta Ichthyologica et Piscatoria 36 (1): 39-47.

DOI: 10.3750/AIP2006.36.1.06

Kolakowski E., Tokarczyk G., Bednarczyk B., Dudzicz M., Przybylski P. 2004. Wstępne badania nad przydatnością lotnych zasad do oceny stopnia świeżości śledzi solonych metodą zalewową. [Preliminary studies on applicability of volatile bases to evaluation of freshness of brine-salted herring.] Folia Universitstis Agriculturae Stetinensis, seria Scientia Alimentaria 238 (3): 71-78. [In Polish.] 
Koral S., Köse S., Tufan B. 2009. Investigating the quality changes of raw and hot smoked garfish (Belone belone euxini, Günther, 1866) at ambient and refrigerated temperatures. Turkish Journal of Fisheries and Aquatic Sciences 9 (1): 53-58.

Losada V., Barros-Velázquez J., Gallardo J.M., Aubourg S.P. 2004. Effect of advanced chilling methods on lipid damage during sardine (Sardina pilchardus) storage. European Journal of Lipid Science and Technology 106 (12): 844-850.

DOI: 10.1002/ejlt.200400991

Maqsood S., Benjakul S. 2011a. Effect of bleeding on lipid oxidation and quality changes of Asian seabass (Lates calcarifer) muscle during iced storage. Food Chemistry 124 (2): 459-467.

DOI: $10.1016 /$ j.foodchem.2010.06.055

Maqsood S., Benjakul S. 2011b. Retardation of haemoglobin-mediated lipid oxidation of Asian sea bass muscle by tannic acid during iced storage. Food Chemistry 124 (3): 1056-1062.

DOI: 10.1016/j.foodchem.2010.07.077

Metin S., Erkan N., Varlik C., Aran N. 2001. Extension of shelf-life of chub mackerel (Scomber japonicus Houttuyn 1780) treated with lactic acid. European Food Research and Technology 213 (3): 174-177.

DOI: $10.1007 / \mathrm{s} 002170100362$

Min B., Ahn D.U. 2005. Mechanism of lipid peroxidation in meat and meat products-A review. Food Science of Biotechnology 14 (1): 152-163.

Neira J.I., Pazos M., Maestre R., Torres J.L., Medina I. 2011. Galloylated polyphenols as inhibitors of hemoglobin-catalyzed lipid oxidation in fish muscle. Journal of Agricultural and Food Chemistry 59 (10): 5684-5691.

DOI: $10.1021 /$ jf200295c

Pietrzyk C. 1958. Kolorymetryczne oznaczanie nadtlenków w tłuszczach za pomocą rodanków żelaza. [Spectrophotometric determination of lipid peroxides by thiocyanate technique.] Roczniki Państwowego Zakładu Higieny 9: 75-84. [In Polish.]

Regulska-Ilow B., Ilow R. 2002. Comparison of the effects of microwave cooking and conventional cooking methods on the composition of fatty acids and fat quality indicators in herring. Nahrung/Food 46 (6): 383-388.

DOI: $10.1002 / 1521-3803(20021101) 46: 6<383:$ AIDFOOD383>3.0.CO;2-L

Simopoulos A. 1997. Nutritional aspects of fish. Pp. 589-607. In: Luten J., Börrensen T., Oehlenschläger J. (eds.) Seafood from producer to consumer, integrated approach to quality. Developments in Food Sciences No. 38. Elsevier, London, UK.

Sae-leaw T., Benjakul S. 2014. Fatty acid composition, lipid oxidation, and fishy odour development in seabass (Lates calcarifer) skin during iced storage. European Journal of Lipid Science and Technology 116 (7): 885-894.

DOI: $10.1002 /$ ejlt.201300381
Shi C., Cui J., Yin X., Luo Y., Zhou Z. 2014. Grape seed and clove bud extracts as natural antioxidants in silver carp (Hypophthalmichthys molitrix) fillets during chilled storage: Effect on lipid and protein oxidation. Food Control 40: 134-139.

DOI: $10.1016 /$ j.foodcont.2013.12.001

Sohn J.-H., Ohshima T. 2010. Control of lipid oxidation and meat color deterioration in skipjack tuna muscle during ice storage. Fisheries Science 76 (4): 703-710. DOI: $10.1007 / \mathrm{s} 12562-010-0248-0$

Šimat V., Bogdanovič T., Poljak V., Petričevic S. 2015. Changes in fatty acid composition, atherogenic and thrombogenic health lipid indices and lipid stability of bogue (Boops boops Linnaeus, 1758) during storage on ice: Effect of fish farming activities. Journal of Food Composition and Analysis 40: 120-125.

DOI: $10.1016 /$ j.jfca.2014.12.026

Tanimoto S., Hirata T., Sakaguchi M. 1999. The change in content of ATP and its related compounds in freshwater Fish muscle during ice storage. Bulletin of the Japanese Society of Scientific Fisheries (Nippon Suisan Gakkaishi) 65 (1): 97-102. [In Japanese.] DOI: $10.2331 /$ suisan.65.97

Thiansilakul Y., Benjakul S., Richards M.P. 2010. Changes in heme proteins and lipids associated with off-odour of seabass (Lates calcarifer) and red tilapia (Oreochromis mossambicus $\times$ O. niloticus) during iced storage. Food Chemistry 121 (4): 1109-1119.

DOI: $10.1016 /$ j.foodchem.2010.01.058

Tokur B. 2007. The effect of different cooking methods on proximate composition and lipid quality of rainbow trout (Oncorhynchus mykiss). International Journal of Food Science and Technology 42 (7): 874-879.

DOI: $10.1111 /$ j.1365-2621.2006.01298.x

Turhan S., Ustun N.S., Temiz H. 2011. Lipid quality of anchovy (Engraulis encrasicholus) fillets affected by different cooking methods. International Journal of Food Properties 14 (6): 1358-1365.

DOI: $10.1080 / 10942911003672159$

Undeland I., Kristinsson H.G., Hultin H.O. 2004. Hemoglobin-mediated oxidation of washed minced cod muscle phospholipids: Effects of $\mathrm{pH}$ and hemoglobin source. Journal of Agricultural and Food Chemistry 52 (14): 4444-4451.

DOI: $10.1021 / \mathrm{jf030560s}$

Verma J., Srikar L., Sudhakara N., Sarma J. 1995. Effect of frozen storage on lipid freshness parameters and some functional properties of oil sardine (Sardinella longiceps) mince. Food Research International 28 (1): 87-90.

DOI: 10.1016/0963-9969(95)93336-S

Wang Y.-J., Miller L.A., Addis P.B. 1991. Effects of heat inactivation of lipoxygenase on lipid oxidation in lake herring (Coregonus arterii). Journal American Oil Chemists' Society 68 (10): 752-755.

DOI: $10.1007 / \mathrm{BF} 02662166$

Wheaton W.F., Lawson T.B. 1985. Processing aquatic food products. John Wiley and Sons, New York, NY, USA. 
Widjaja W.P., Abdulamir A.S., Abu Bakar F.B., Saari Yarnpakdee S., Benjakul S., Nalinanon S., Kristinsson N.B., Ishak Z.B., Hamid A.A. 2009. Lipid quality deterioration of Bagridae catfish (Mystus nemurus) during storage. Research Journal of Biological Sciences 4 (4): 525-530.

H.G. 2012. Lipid oxidation and fishy odour development in protein hydrolysate from Nile tilapia (Oreochromis niloticus) muscle as affected by freshness and antioxidants. Food Chemistry 132 (4): 1781-1788.

DOI: 10.1016/j.foodchem.2011.11.139

Received: 27 July 2016

Accepted: 3 July 2017

Published electronically: 30 September 2017 